is already stretched.

But the officials agree that they might become interested if the costs of the programme were shared with international partners. "We are certainly not dismissing it [the proposal]," says one official in London.

Indeed, ESA agrees that its plans are only to be achieved by a global programme. Next week, the agency will host a workshop in Switzerland on plans to study and explore the Moon. The meeting will also be attended by representatives of NASA, as well as of the Russian, Japanese and European space agencies.

Some NASA scientists, conscious that Congress would reject any plan for a NASA Moon mission, are beginning to talk of the ESA proposal as a way back into action. They believe it could revive flagging US interest in the Moon.

Wendel Mendell of NASA's Johnson Space Center says that the ESA proposal is "totally independent of NASA, which to me is good news". He adds that the US Congress is likely to accept a lunar exploration plan only "if it is brought to the table by an external party".

Jean-Jacques Dourdain, associate director for strategy, planning and international policy at ESA, describes the Moon as a "suburb" of Earth, and says that a lunar mission is inevitable at some point. He argues that the time is now right for space agencies to recapture the momentum that has been lost in space exploration.

Dourdain adds that ESA will not oversell the potential industrial spin-offs of a Moon mission - a mistake he says was made with attempts to use microgravity research, which has been used to "sell" the space station. He says that ESA is keen to assemble a "credible" plan that it can present to its member states and potential foreign partners.

Declan Butler \& Tony Reichhardt

\title{
Switzerland eyes the costs of joining Framework
}

Basel. Swiss scientists are growing increasingly nervous that their government's enthusiasm for participating in the European Union (EU)'s fourth five-year Framework programme may take money away from basic research in order to cover the higherthan-anticipated costs that its participation would involve.

Last week, the foreign ministers of the EU announced in Brussels that bilateral negotiations with Switzerland will start "as soon as possible". Officials in Berne expect that the next research ministers' meeting at the end of June will open the way for bilateral talks about Framework.

Initial discussions took place two years ago, in the context of Switzerland possibly becoming a member of the European Economic Area (EEA). Since the beginning of this year, countries in the EE $\Lambda$ - such as Sweden, Austria and Finland -.- have automatically participated in Framework.

Although Swiss voters rejected the EEA proposal at the time in a referendum, they approved the idea of participating in Framework. If parliament agrees, delegations from Berne and Brussels will meet later this year to start talks on a bilateral agreement for Swiss participation in European research programmes.

But calculations of its potential financial commitment were based on the ECU6.6 billion costs of the third five-year Framework programme (1989-93). In December 1992 the Swiss parliament approved SF477 million for participation in European research programmes for a four-year period.

\section{Election costs hit Pretoria science budget}

Cape Town. South Africa is not spending enough on research and development, according to the country's new Minister for Arts, Culture, Science and Technology, Ben Ngubane, speaking in his first public address at the Human Sciences Research Council in Pretoria last week.

Ironically, however, Ngubane's speech, in which he committed himself to working towards "more focused and effective science and technology", came only days after the country's three largest science councils had been informed of cuts in their parliamentary grants for the current financial year.

These cuts are part of an across-theboard reduction of 5 per cent of this year's budget for all government departments, rather than a reflection of any deliberate effort to reduce the science budget. Furthermore the overall cut was imposed not by the new cabinet, but by its predecessor, in order to finance a R1-billion ( $\$ 272$ million) bill for the recent election.

The reduction has had different consequences for the various research councils because the science vote, despite being voted on as a single budget item, is allocated to five 'mother' departments as funds earmarked for the councils. Departments have been allowed to exercise discretion on where the cuts are applied.

The Foundation for Research Development's R16 million allocation for new equipment in the universities has been cut to R6 million. The largest council, the Council for Scientific and Industrial Research, has been notified of a 5.5 per cent cut to its budget, and the Agricultural Research Council will have its budget reduced by slightly less than this. The three smaller councils - including the Medical Research Council - appear to have escaped the knife. Michael Cherry
In contrast, the budget for the fourth Framework will be ECU12 billion (the increases result primarily from additional European Commission projects). This will mean an expected cost to Switzerland of SFr800 million. And the need to find an additional annual SFr60-70 million on top of funds already approved by the parliament comes at a time when the federal government's finances are already tight.

Jean-Pascal Delamuraz, the Swiss Economic Minister, says that a definite solution has not yet been reached. "We will see whether it is really necessary to pay so much to take part in EU programmes and whether we will have to sacrifice something."

Rather than reduce its level of participation - which would need negotiating with Brussels - the government would prefer to find the extra money from research funds that would otherwise have been spent inside Switzerland.

Tim Guldimann, of the Gruppe für Wissenschaft und Forschung, which advises the Swiss government on research and science policy, says that about half the outstanding amount would have to be found from other budgets. But he points out that, providing Swiss researchers are successful in applying for grants from Brussels, more than SFr200 million will be returned to the country each year.

Nevertheless, many Swiss researchers fear that participation in European programmes could lead to reduced funding for basic research in Switzerland itself. Most research administrators agree in principle that the 'compensation' solution is appropriate, but no-one is eager to see his or her budget cut.

Hans Peter Hertig, general secretary of the Swiss National Science Foundation, the state agency that funds basic research, says he supports Swiss participation in European-level programmes funded through Brussels, but not at the price of a reduction in basic research at home.

"The fourth framework is mainly about applied research carried out in collaboration with industry", says Hertig. He argues that money earmarked for applied research in Switzerland might more suitably be transferred to finance the European participation, and that funding for basic research should be protected.

Paul-Erich Zinsli, vice-director of the Ministry of Interior's department for research, also feels that compensation should be restricted to applied research, and that steps should be taken to preserve the country's fundamental research base. "Otherwise we could not contribute to European science in the long run," he says. 